\title{
Spatial analysis, local people's perception and economic valuation of wetland ecosystem services in the Usumacinta floodplain, Southern Mexico
}

\author{
Vera Camacho-Valdez ${ }^{1}$, Andrea Saenz-Arroyo \\ Andrea Ghermandi ${ }^{3}$, Dario Alejandro Navarrete-Gutierrez ${ }^{4}$, \\ Rocío Rodiles-Hernández ${ }^{2}$ \\ ${ }^{1}$ Departamento de Conservación de la Biodiversidad, CONACYT-El Colegio de la Frontera Sur, San Cristóbal de las Casas, Chiapas, Mexico \\ 2 Departamento de Conservación de la Biodiversidad, El Colegio de la Frontera Sur, San Cristóbal de las Casas, Chiapas, Mexico \\ 3 Department of Natural Resources and Environmental Management, University of Haifa, Haifa, Haifa, Israel \\ 4 Laboratorio de Análisis de Información Geográfica y Estadística, El Colegio de la Frontera Sur, San Cristóbal de las Casas, Chiapas, Mexico \\ Corresponding Author: Andrea Saenz-Arroyo \\ Email address: msaenz@ecosur.mx
}

The Usumacinta floodplain is an exceptional area for biodiversity with important ecosystem services for local people. The main objective of this paper was to estimate reference values and define local perceptions of ecosystem services provided by wetlands and overlapping them with spatially explicit socioeconomic and biodiversity indicators. We used the Usumacinta floodplain as an example of a territory where high dependence of rural people on ecosystem services is confronted with development projects that threat the flow of ecosystem services, thus affecting rural people well-being. With a combination of data from remote sensing, global databases of ecosystem service values, local perception of ecosystem services and socioeconomic and biodiversity richness indicators in a spatially explicit framework, we develop a policy-oriented approach for rapid assessment to manage wetlands and maintain people's livelihoods. Regulating and provisioning services are identified as the most relevant ecosystem services in terms of their monetary value and local perceived importance. In a spatially explicit manner, this approach highlights the most valuable wetlands and identifies rural societies that are highly dependent on ecosystem services. Our approach can be replicated elsewhere and could provide valuable information for policymakers to design policies that can contribute to conserve wetland ecosystems where under threat of development. 
1 Spatial analysis, local people's perception and

2 economic valuation of wetland ecosystem services in

3 the Usumacinta floodplain, Southern Mexico

\section{Vera Camacho-Valdez ${ }^{1}$, Andrea Saenz-Arroyo ${ }^{2, a}$, Andrea Ghermandi ${ }^{3}$, Darío Alejandro}

Navarrete-Gutiérrez ${ }^{4}$ and Rocío Rodiles-Hernández ${ }^{2}$

${ }^{1}$ Departamento de Conservación de la Biodiversidad, CONACYT- El Colegio de la Frontera Sur, San Cristóbal de las Casas, Chiapas, México

${ }^{2}$ Departamento de Conservación de la Biodiversidad, El Colegio de la Frontera Sur, San

Cristóbal de las Casas, Chiapas, México

${ }^{3}$ Department of Natural Resources and Environmental Management, University of Haifa, Haifa, Israel

${ }^{4}$ Laboratorio de Análisis de Información Geográfica y Estadística, El Colegio de la Frontera Sur, San Cristóbal de las Casas, Chiapas, México

Corresponding Author:

Andrea Sáenz-Arroyo

Carretera Panamericana y Periférico Sur s/n, Colonia María Auxiliadora, San Cristóbal de las

Casas, Chiapas, 29290, Mexico

Email address: msaenz@ecosur.mx

\section{Abstract}

The Usumacinta floodplain is an exceptional area for biodiversity with important ecosystem services for local people. The main objective of this paper was to estimate reference values and define local perceptions of ecosystem services provided by wetlands and overlapping them with spatially explicit socioeconomic and biodiversity indicators. We used the Usumacinta floodplain as an example of a territory where high dependence of rural people on ecosystem services is confronted with development projects that threat the flow of ecosystem services, thus affecting rural people well-being. With a combination of data from remote sensing, global databases of ecosystem service values, local perception of ecosystem services and socioeconomic and biodiversity richness indicators in a spatially explicit framework, we develop a policy-oriented approach for rapid assessment to manage wetlands and maintain people's livelihoods. Regulating and provisioning services are identified as the most relevant ecosystem services in terms of their monetary value and local perceived importance. In a spatially explicit manner, this approach highlights the most valuable wetlands and identifies rural societies that are highly dependent on ecosystem services. Our approach can be replicated elsewhere and could provide valuable information for policymakers to design policies that can contribute to conserve wetland ecosystems where under threat of development. 


\section{Introduction}

41 The need to accommodate both the challenges of improved environmental conservation as well

42

43

44

45

46

47

48

49

50

51

52

53

54

55

56

57

58

59

60

61

62

63

64

65

66

67

68

69

70

71

72

73

74

75

76

77

78 as maintaining cultural diversity and wellbeing of vulnerable sectors of the population has played a central role in the development of the ecosystem services framework and conservation discourse (Daly 1997; MEA 2005; Durand 2019). In this context, wetland ecosystems, such as those occurring in floodplains, have been the subject of numerous ecosystem service assessments and valuations worldwide (Kanyiginya et al. 2010; Rongoei et al. 2013; Richarts et al. 2015; Ghermandi et al. 2010), due to the crucial role they play in supporting the livelihoods of local populations through their provisioning (e.g., fibre, water, food, fuel wood, natural medicines), regulating (e.g., flood control, water quality improvement), and cultural services (e.g., support of recreation, aesthetic value, support of educational activities) (TEEB in Policy 2011).

In spite of their social and ecological importance, floodplain wetlands are threatened worldwide mainly due to land use conversion for economic activities such as agriculture, tourism, urban development, forestry and fossil energy production (Renaud et al. 2013; Day et al. 2016). For example, a global overview of dam-based impacts on large river systems shows that over half are affected by dams, thereby resulting in the alteration of functional processes and diminishing of the provision of ecosystem services to local societies (Nilsson et al. 2005). From an economic perspective, such alterations can be seen as the outcome of the undervaluation of the public goods and services provided by these ecosystems in decision-making processes regarding their use, management and conservation (Brander et al. 2012).

The Usumacinta floodplain, a 700,000 ha wetland ecosystem in Southern Mexico which was selected as case-study site for the present research, is representative of the above mentioned global trend. Since the 1980s, the discovery of a large hydrocarbon deposit on the marine platform near the floodplain has led to major land use changes in the region, making the oil industry one of the main economic activities in the area (Yáñez-Arancibia et al. 2009). This development, together with other activities such as intensive agriculture and stockbreeding, has increased the exploitation and deterioration of the wetland ecosystem, declining the provision of ecosystem services to local communities (García-Cuéllar et al. 2004; García and Kauffer 2011). Although there have been governmental efforts to protect the ecosystems by declaring two important wetlands within the floodplain as natural protected areas (Centla Swamps and Terminos Lagoon, respectively in 1992 and 1994), a recent spatial analysis shows that this area in particular the Centla Swamps Biosphere Reserve - has experienced dramatic transformations in the last 20 years, from natural floodplain vegetation to cattle and agricultural areas (RosaVelázquez et al. 2017; Ghermandi et al. 2020) which carries with economic difference such as the concentration of benefits as well as environmental and social problems (Durand 2019). In order to reverse this trend and guarantee the access of communities to environmental resources and the preservation of sustainable livelihoods, more democratic local policy interventions are needed (Sundberg 2003) to steer these processes and mitigate their negative impacts on ecosystems and society in general (Adams 2004). An analysis of the relationship between 
79

80

81

82

83

84

85

86

87

88

89

90

91

92

93

94

95

96

97

98

99

100

101

102

103

104

105

106

107

108

109

110

111

112

113

114

115

116

117

118

cultural identity and conservation is essential to dealing with the environmental issues (Sundberg 2006)

Since policies targeting biodiversity conservation may have important social implications, it is necessary to develop assessments that include relevant a range of social, ecological and economic aspects (Schmidt et al. 2016; Ciftcioglu 2017) as well as local people's perspective of what is important to preserve. In this regard, the ecosystem service framework may help to understand user preferences and relative values placed on ecosystem services (de Groot et al. 2012). In turn, this provides important support information for policy-makers and stakeholders to make informed decisions involving wetland resource allocation when faced with competing uses (Chaikumbung et al. 2016) as well as to implement more integrative and effective conservation strategies that recognize the needs of local people and the economic costs of private or public interventions (Camacho-Valdez et al. 2013; Adusumilli 2015).

Despite the emphasis that is placed in the literature on the importance of integrating the social, ecological, and economic aspects in the evaluation of ecosystem services, most empirical studies in the international arena rely on assessments derived from single disciplinary approaches (Gómez-Baggethun et al. 2014). In particular, while the need is recognized to complement instrumental perspectives often based on monetary-based approaches to the assessment of ecosystem service values with a more pluralistic approach explicitly embracing, among others, socio-cultural and biophysical measures (IPBES 2016), a unified theoretical framework is still lacking. There is a need for more integrative empirical studies combining tools and assessment methods from different disciplines. This is arguably particularly true in rural and remote areas where the linkage between ecosystem services and human well-being occurs at finer spatial scales (Wu 2013). One should note that such pluralistic valuation approach does not entail a rejection of monetary valuation techniques per se, but rather emphasizes the benefits of integrating them with the complementary information that can be obtained through a broad suite of valuation methods (Bernues et al 2014; Wam et al. 2016; Jacobs et al. 2016).

In recent years, spatial analysis through Geographic Information Systems (GIS) has been increasingly relied upon in the investigation and representation of the ecosystem services provided by different ecosystems at a range of different scales (Naidoo et al. 2008; Luck et al. 2009; Lautenbach et al. 2011; Lavorel and Grigulis 2012; Ghermandi et al. 2013). Spatially explicit assessments can be helpful for instance in analyzing trade-offs and synergies among ecosystem services in a particular landscape (Raudsepp-Hearne et al. 2010). In this context, ecosystem services mapping is becoming an important tool for land-use planning and conservation-related decision-making (Burkhard and Maes 2017).

This paper integrates spatial analysis with results from different ecosystem service assessment methods relying both on monetary valuation techniques and participatory, sociocultural valuation techniques applied in the local communities to provide useful, spatially explicit insights on the provision of wetland ecosystem services in the Usumacinta floodplain, with a particular focus on producing valuable information for the local environmental decision makers. More specifically, we aim at identifying important wetland ecosystem services through 
119 the combination of different monetary and non-monetary valuation techniques and combining 120 such information with indicators of biodiversity and socioeconomic marginalization to identify

121 priority areas for wetland conservation. First, a spatial analysis of the wetland types that are

122 present in the Usumacinta floodplain is performed, taking advantage of the use of remote sensing

123 and GIS. Through the application of value transfer techniques, reference monetary values for

124 different ecosystem services provided by the identified wetland types were calculated. We

125 contrasted these results with the perspective of local inhabitants with respect to wetland

126 ecosystems services in four communities located in the study area. The study finally explores the

127 spatial variability of the estimated ecosystem service values as they overlap with spatially

128 explicit indicators of the socioeconomic marginalization of the local population and biodiversity

129 richness, to provide a multidimensional perspective on priority areas for natural capital

130 conservation within the study area.

131

\section{Study area}

133 The study site has a surface of approximately 2.5 million ha and is located between the states of

134 Campeche, Tabasco and Chiapas, in southern Mexico. The floodplain is part of the Usumacinta

135 watershed and comprises a main river, the Usumacinta, a major tributary, the Grijalva River, and

136 the Terminos Lagoon (Fig. 1). Over the past 50 years, four large dams have been built along the

137 Grijalva River causing significant impact on the surrounding landscape, watershed fragmentation

138 and changes in the natural water flow regulation (Wilkerson 1986; Muñoz-Salinas and Castillo

139 2015). The main physical factors that affect the Usumacinta floodplain wetlands are: a)

140 precipitation, b) flood pulses, and c) the coastal plain of Tabasco and Campeche. Freshwater

141 pulses with high suspended sediments, inorganic nutrients and organic materials generate

142 extensive wetlands such as Terminos Lagoon and Centla Swamps, the latter being the largest

143 coastal lowland wetland in Mesoamerica (Yañez-Arancibia et al. 2009).

144 Before the development of the oil industry in the 1980s, fishing was the main economic

145 activity in this region (Tudela 1989). The lagoon and its associated habitats serve as nursery and

146 feeding areas for important species of shrimp and about 214 species of fish in the southern Gulf

147 of Mexico (Lara-Dominguez et al. 1993). Previous studies have shown that fishery resources in

148 Campeche Sound and Terminos Lagoon depend strongly on the supply of nutrients, organic

149 matter, flood pulses and the movement of pre-adult fish and shrimp from the lagoon-estuarine

150 system to the sea caused by tidal action (Deegan 1986; Yañez-Arancibia et al. 1992). Fisheries

151 also include reef fish, coastal migratory pelagic fish, and large oceanic pelagics of great

152 importance at an international level (Yañez-Arancibia and Day 2004), which also depend on the

153 ecological integrity of the Usumacinta floodplain system, its waters and the quality of their

154 habitats.

155 Overall, 14 municipalities are located in the study region, all showing high degrees of

156 marginalization, with the exception of Carmen and Centro. Ciudad del Carmen is the most

157 important city, with a population of 221,000 inhabitants and infrastructure to support the oil

158 industry and other economic activities (e.g., tourism, fishing, harboring) (INEGI 2010). The 
159

160

161

162

163

164

165

166

167

168

169

170

171

172

173

174

175

176

177

178

179

180

181

182

183

184

185

186

187

188

189

190

191

192

193

194

195

196

study area is mostly characterized by a warm, humid climate with $1,200-2,500 \mathrm{~mm}$ rainfall during the summer and an average annual temperature of $26-27^{\circ} \mathrm{C}$ (INEGI 2008).

\section{Materials \& Methods}

The methodological approach used in this research draws from various disciplines and includes: (i) the classification and characterization of spatial distribution of land use and wetland ecosystem types through remote sensing and GIS techniques; (ii) the valuation of local wetland ecosystem services based both on the results of an international value transfer exercise and (iii) the analysis of the perception of ecosystem services as elicited by local inhabitants through semistructured interviews; and (iv) an analysis of the spatial overlap of the estimated ecosystem service values with selected indicators of population marginalization and biodiversity richness in order to provide policy-relevant information for decision-makers (Fig. 2).

Spatial analysis of wetland ecosystems distribution

Different types of floodplain wetlands, their distribution and extension were identified from the classification of Landsat 8 OLI (path /row: 21/47; 22/47 and path /row: 21/48; 22/48) images acquired in April, May and November 2014. IDRISI Selva and ArcGIS 10 were used for the classification process and for the final coverage map. Before starting the classification procedure, Landsat image was limited to the margins of the physiographic province of the Southern Gulf Coastal Plain (INEGI 2008) using a masking process, and geographically projected to the UTM zone 15 North (WGS84). Subsequently atmospheric correction was performed using the Idrisi Selva AtmosC module. The atmospheric correction is an essential requirement to have an accurate representation in the analysis of the surface properties from satellite images (Mahdavi et al. 2018).

The classification process was carried out using a supervised method which required the user to identify the wetland types, digitizing on-line from a color composite image a sample of pixels (training sites) for each cover. Using the maximum likelihood algorithm individual pixels were assigned to the cover class with the highest degree of similarity (Campbell 1996). For the definition of the wetland types present in the study area, the Mexican wetland classification proposed by Berlanga et al. (2008) was used.

The accuracy of the final map was assessed by an error matrix and the Kappa index (K'). An error matrix was developed using 30 test points per class as reference data and compared by cross-tabulation with pixels from the classification. Coincidences between both datasets (main diagonal) were used to estimate the overall accuracy (\%) and Kappa coefficient (K') to measure the correspondence between the classification and the reference data (Congalton and Green 1999). The test points for the analysis were randomly selected from the resulting final map and field validated with the assistance of a GPS. The accuracy for the classification was $86 \%$ and the Kappa coefficient was 0.85 , indicating that the classification results meet the accuracy requirement of land cover classification.

Wetland ecosystem services in the Usumacinta floodplain 
197

198

199

200

201

202

203

204

205

206

207

208

209

210

211

212

213

214

215

216

217

218

219

220

221

222

223

224

225

226

227

228

229

230

231

232

233

234

235

\section{Ecosystem services valuation}

Although previous research recommends the application of primary valuation techniques as the preferred approach to the monetary valuation of ecosystem services (Farber et al. 2006), conducting such studies at large scales is often not a viable option due to time and funding constraints, lack of the necessary infrastructure, and the inherent, logistical difficulties (Shrestha and Loomis 2001; Rosenberger 2015). As a second-best option, benefit transfer methods have been widely applied (Johnston et al. 2015). Such techniques rely on the application of monetary values and other information derived from the original study site(s) to a policy site (Liu et al. 2012). Some of the main limitations of benefit transfer include data availability and reliability, distribution of data on services and values over biomes, differences in socio-economic context, and spatial heterogeneity (de Groot et al. 2012). The consensus among value transfer practitioners is that the more similar the study and policy are, the more accurate the value transfer will be (Rosenberger and Phipps 2007; Johnston and Rosenberger 2010; Kaul et al 2013; Rosenberger 2015). However, the literature has yet to agree on a set of criteria for site similarity (Johnston and Rosenberger 2010). Given the constraints of the present study as well as the general lack of suitable primary valuation studies from coastal wetlands in Mexico, whereby most available valuations focus on mangrove ecosystem services (Lara-Dominguez et al. 1993; Barbier and Strand 1998; Mendoza et al. 2012), this study relies on an international value transfer to provide a first estimate of the multiple ecosystem services delivered by each wetland type and integrate them in further analysis. International datasets of 216 coastal wetland ecosystem service valuations (Ghermandi et al. 2010; Van der Ploeg et al. 2010) were used to infer the average values for each of the wetland types located in the case-study area. Although other wetland valuation databases have been produced in the literature (e.g., Chaikumbung et al 2016; Camacho-Valdez et al 2013), such datasets were selected upon considerations regarding the relevance for the investigated study region and their accessibility. To avoid double counting value estimates, studies that value two or more services or that estimate total economic value were not taken into account in the transfer. Values were presented in common monetary units (USD/ha/year), inflation-adjusted to 2007 USD (Eade and Moran 1996; Costanza et al. 1997; Wilson et al. 2004) and organized for the corresponding services within each of the wetland types. We determine the minimum, maximum, standard deviation and median of the economic values for most services in each wetland type (see Appendix A provided as online supplementary information). The estimated total value associated with each wetland ecosystem service within the Usumacinta floodplain (in \$US 2007 per year) was estimated multiplying the median perhectare value by the total area of each wetland type, as derived from the spatial analysis. Finally, the estimated values were spatially represented across the Usumacinta floodplain, displaying the value of the annual flow of services provided by each wetland type.

\section{Local perception of ecosystem services}

In order to complement the ecosystem service value information derived from the international value transfer exercise and to partially account for the lack of local ecosystem service valuations, 
236

237

238

239

240

241

242

243

244

245

246

247

248

249

250

251

252

253

254

255

256

257

258

259

260

261

262

263

264

265

266

267

268

269

270

271

272

273

274

275

a qualitative study of ecosystem service values was implemented using a participatory approach in four typical villages distributed along the main type of wetlands of the Usumacinta floodplain region (Fig. 1). The aim of this implementation was to compare the results obtained with both methods, looking for similarities and differences, as well as better highlight the dependence of local people from wetland ecosystem services. To achieve this, we collected relevant data combining four different categories:

1) Ecosystem services: benefits people obtained from ecosystems, including provisioning (e.g., support of commercial fishing), regulating (water quality improvement), habitat, and cultural services (e.g., recreation) (TEEB 2011).

2) Capitals: benefits which are expressed in the form of capital accumulated through the use of ecosystem services in human livelihoods (Scoones 1998), such as human capital (e.g., health), social capital (e.g., associations) and man-made capital (e.g., income).

3) Main activities: productive activities of rural populations (e.g. fishing, tourism).

4) Main threats: threats and their possible impacts related to exogenous changes, both climatic and anthropogenic (e.g. water contamination, deforestation).

The methods applied to understand the importance of ecosystem services and its associations to local people's livelihoods were based on the FABE's approach (Hare and PahlWostl 2002; Pahl-Wostl and Hare 2004; Hare 2011), which is generally used to build system dynamics models on local people's dependence to natural capital. By incorporating the sustainable livelihoods approach (Scoones 1998), the use of natural capital is understood on how is transformed in different forms of capital such as human capital, social capital, economic capital and infrastructure. Each of the interviewers made one casual loops model linking ecosystems attributes, with the benefits and threats they perceive where affecting their livelihoods as proposed by Fisher et al. (2013).

Ten semi-structured in-depth interviews were conducted between October 2014 and March 2015 in each of the four communities selected (Fig 1.). They were organized following the previously defined categories that were covered during the course of the interview, instead of a sequenced script of standardized questions. Such format for the semi-structured interviews allows for more focused, conversational, two-way communication (Meli et al. 2015). Interviews were developed around initial questions such as "What does the river mean to you?", "What do you eat normally?", "Where does your income come from?", "What kinds of problems are you mostly concerned about?". Also, in the course of each semi-structured interviews, the interviewers used the method of "cognitive mapping" (Hare 2011) to develop on paper, cognitive maps of individual perspectives for each of the respondents. All interviews were digitally recorded and professionally transcribed based on the "Grounded Theory" (Glaser and Strauss 1967) and the four previously defined categories. Subsequently, an individual qualitative conceptual model for each participant was built on a computer (Fig 3.).

The selection of the communities was based on the following criteria : 1) location, 2) population, 3) type of settlement, 4) antiquity, 5) level of transformation of the environment, 6) economic activities, 7) ethnicity, 8) level of marginalization (education level), and 9) researchers' 
276 safety (Table 1). With the support of the National Commission of Natural Protected Areas

277 (CONANP), communities in the region that met these criteria were selected. Once the four

278 communities were identified, the delegate of each community was contacted and with their help,

279 ten members were chosen in each of them. In the application, care was taken that the interviews

280 would reflect a representation of ages, gender, educational levels and social sectors in order to

281 have a wide representation of the uses of the ecosystems. Although we acknowledge that a larger

282 number of interviewees and communities would provide a more comprehensive perspective on

283 local ecosystem service perceptions, a more thorough investigation was not possible within the

284 constraints of the study. Yet, we believe the present results to be valuable in an area with severe

285 limitations in data availability. It is stressed that this research reports only results concerning the

286 ecosystem services identified by local communities in order to highlight the local dependence of

287 people from wetlands. The results of the other categories will be analyzed in depth in another

288 article that is in preparation.

289 Spatial analysis of value flows in their socioeconomic and biodiversity context

290 In order to spatially investigate the link between the socioeconomic status of the population,

291 biodiversity and the elicited ecosystem service values, we used a set of indicators and GIS to

292 superimpose the different layers of information. The number of bird species present in the

293 Usumacinta floodplain area was used as a proxy for biodiversity richness. Birds are among the

294 best-studied organisms worldwide and they are often considered as good ecological proxies to

295 assess the biodiversity values of an area, even for other taxa which are difficult to sample

296 (Prendergast et al. 1993; Kati et al. 2004; Maccherini et al. 2009; Santi et al. 2010). The bird

297 species distribution maps produced by BirdLife International and NatureServe (2014) were used

298 to derive the number of bird species observed in the Usumacinta floodplain, rasterized at a 30-m

299 resolution. The socioeconomic marginalization index produced by the National Population

300 Council (Mexico) (http://www.conapo.gob.mx/es/CONAPO/Indices_de_Marginacion),

301 estimated at the municipal level for the 14 municipalities in the Usumacinta floodplain, was used

302 to outline economic vulnerability in the area. Following the methodology of Ghermandi et al.

303 (2013), the spatial overlap of such indicators with the value of the flow of ecosystem services

304 was explored, both at a high resolution (30-m grid cells) and aggregated at the level of

305 municipalities. This analysis was primarily targeted at providing relevant information for the

306 development of environmental policy instruments through the identification of priority

307 conservation areas.

\section{Results}

309 Ecosystems classification and land cover map

310 The results of the classification of wetland types and land use covers in the Usumacinta

311 floodplain are shown in Figure 4. The map indicates that urban areas, agriculture, wetlands

312 (coastal lagoon, mangrove, riverine, palustrine and lacustrine) and other inland cover areas are

313 the dominant cover types in the study area. 
314

315

316

317

318

319

320

321

322

323

324

325

326

327

328

329

330

331

332

333

334

335

336

337

338

339

340

341

342

343

344

345

346

347

348

349

350

351

Considering the classification results, agriculture was the most widely represented land use $(1,018,186 \mathrm{ha})$, covering $21 \%$ of the entire area. Among wetlands, the largest ecosystems are palustrine, covering 320,285 ha $(12 \%)$ of the total surface in the study area. Palustrine and coastal lagoon ecosystems were the most important wetlands in terms of coverage $(548,486 \mathrm{ha})$, representing $71 \%$ of the total area of wetlands. Mangroves, riverine and lacustrine ecosystems occupy substantially smaller areas (Table 2).

\section{Wetland ecosystem service values}

\section{Monetary values from benefit transfer}

The results of the international value transfer analysis are presented in table 2 . The number of blank cells represents data gaps in the dataset. Overall, there is considerable variability in ecosystem service values delivered by different wetland types. On a per-hectare basis, the riverine ecosystem was the coverage with the highest annual median value of $\$ 12,833$ USD/ha/year. The mangrove, palustrine and lacustrine ecosystems also contribute significantly to the valuation analysis with a median value of $\$ 2,653, \$ 9,689$ and $\$ 6,366 \mathrm{USD} / \mathrm{ha} /$ year, respectively. Coastal lagoons were the wetland type with the lowest median value of $\$ 1,926$ USD/ha/year (Table 2).

The total economic values of ecosystem services show a considerable variability. Habitat for species was the ecosystem service with the highest median value $(\$ 6,785 \mathrm{USD} / \mathrm{ha} /$ year), followed by flood control and storm buffering and recreational activities $(\$ 6,677$ and $\$ 5,093$ USD/ha/year, respectively). In general, cultural services are the most valued (Table 2).

The value of the annual flow of ecosystem services delivered by each type of ecosystem in the Usumacinta floodplain, calculated as the product of each ecosystem service median value per area of the corresponding wetland type (Table 2), was over $\$ 4,000$ million USD/year. Of all wetlands included in the analysis, the palustrine ecosystem is one that contributed the highest annual flow (\$3,698 million USD/year), due to its substantial representation in the total area of the case study $(12 \%)$ combined with its relatively high value $(\$ 9,689 \mathrm{USD} /$ ha/year). Estuarine ecosystems (coastal lagoons and mangroves) together with the riverine ecosystem make an important contribution to the total economic value of approximately $\$ 1,000$ million USD/year, while the lacustrine ecosystem made the smallest contribution (\$397 million USD/year).

\section{Importance of ecosystem services for local livelihoods}

The analysis of semi-structured interviews allowed us to identify the dependence of local people on wetland ecosystems through the provision of ecosystem services. Respondents to the survey were all adults ( $>18$ years) whose average age and time living in the community were 52 (range between 28 and 82 years) and 32 years, respectively; $57.5 \%$ were male and $42.5 \%$ female.

Figure 5 shows that 15 types of ecosystem services are important to local people. Among these ecosystem services, the greatest number of services mentioned in the interviews are those corresponding to the provisioning (39\%), followed by cultural $(26 \%)$ and finally regulating services (13\%). Assessment of the provisioning services shows that the current wetlands provide 
352

353

354

355

356

357

358

359

360

361

362

363

364

365

366

367

368

369

370

371

372

373

374

375

376

377

378

379

380

381

382

383

384

385

386

387

388

389

390

391

diverse ecosystem services for the local people, highlighting food ( $85 \%$ ), support of commercial fishing $(80 \%)$, and fuel wood $(65 \%)$. Other services frequently identified were water supply $(52.5 \%)$, harvesting of natural materials $(50 \%)$, amenity and aesthetics $(45 \%)$, medicinal resources $(40 \%)$, and recreational activities $(32.5 \%)$. Flood control and storm buffering was the service least often identified by respondents (5\%).

Comparing these results with the estimates obtained through the benefit transfer exercise reveals that the most valuable ecosystem services differ depending on the context. Cultural services are highlighted as the most valuable services by global studies while provisioning services are the most mentioned by local people. This differentiation may be due design of semistructured interviews that were aimed at understanding the dependence of local communities on the ecosystem services that are most immediately tangible to them, such as of provisioning, as opposed to cultural and regulating services which are provided in an indirect way.

\section{Mapping the dependencies of ecosystem service values, biodiversity and socio- economic indicators}

Overlapping the distribution of the estimated monetary ecosystem service values with the selected biodiversity and socio-economic indicators reveals important multi-dimensional information for the sustainable management of wetland ecosystems in the Usumacinta floodplain. Figure 6a ranks wetland grid cells (mapped at a 30-m resolution) based on wetland conservation priority. The latter is determined as follows: cells in which the values of all three individual layers are in the upper $25 \%$ ile of the respective layer are classified as very high priority; wetland cells with values of only one or two layers in the upper quartile are classified as median and high priority respectively, irrespectively as to which layers rank highly. Figure 6a shows that the majority of high priority conservation areas were concentrated in the municipalities of Palizada, Jonuta, Centla and Carmen. However, the highest degree of overlap between biodiversity, socioeconomic marginalization and ecosystem service values is observed in more isolated wetland ecosystems located in the municipalities of Candelaria and Palenque.

Given that most policy-relevant decisions are taken at the level of administrative regions, in Figure $6 \mathrm{~b}$ each of the municipalities in the Usumacinta floodplain is attributed a unique combination of three color bands, which reflect each of the three components of analysis: (i) blue for aggregate ecosystem service value; (ii) red for socioeconomic marginalization; and (iii) green for biodiversity richness. The values of each of the three indexes is standardized to range between 0 (minimum value) and 255 (maximum value). The saturation of the color in each band is determined by the local value of the indexes. For instance, municipalities where the ecosystem service value (e.g. Carmen) or the socioeconomic marginalization (e.g. Balancán, Jalapa, Escárcega and Champotón) components prevail over the other two are shown in blue and red colors, respectively. In yellow regions (e.g. Palenque, La Libertad and Catazajá) high biodiversity (green) and socioeconomic marginalization levels (blue) are combined with a relatively low value of the flow of ecosystem services. Municipalities with high values for each of the indexes are represented in light grey or off-white colors (e.g. Palizada). In general, Palizada municipality is depicted in white, indicating high values for each of the three indicators. 
392

393

394

395

396

397

398

399

400

401

402

403

404

405

406

407

408

409

410

411

412

413

414

415

416

417

418

419

420

421

422

423

424

425

426

427

428

429

430

431

Comparing these findings with the local perception analysis highlights that the interviewed communities are distributed differently with respect to the spectrum of priority areas. For instance, Quintin Arauz and Tembladeras are located in an area of high socioeconomic marginalization and high ecosystem value (magenta).

\section{Discussion}

The present study provides a multi-dimensional perspective and spatial analysis of the provision of ecosystem services in a rural, largely marginalized region of Mexico, which (1) complements conventional economic valuation techniques with local people's perceived importance of these services, and (2) integrates ecosystem service values into the broader context identified by the local biodiversity richness and socio-economic conditions with the purpose of providing policy guidance for the sustainable management of the rich local natural capital.

Previous analyses have demonstrated that complex relationships exist between economic development and ecosystem degradation (das Neves Almeida et al. 2017), as well as between the provision of ecosystem services and biodiversity indicators (Naidoo et al. 2008). This implies that attention to the local conditions and the integration of insights from different approaches and disciplines is fundamental in the evaluation of different policy options and setting of conservation or development priorities.

The valuation component of the present study relies on two different approaches to elicit the contribution of different wetland ecosystem services to the well-being of the local populations. The monetary valuation results suggest that wetlands in the Usumacinta floodplain generate a substantial economic value, which we estimate around \$USD 5,000 million per year from a wetland area of 773,707 ha. The limitations of the simple value transfer methodology applied in this study include the inherent difficulties involved in international value transfer (Lindhjem and Navrud 2008) and the potential overdue influence that individual value observations may have on the results (Pendleton et al. 2016). In spite of such limitations, the elicited values are meant to provide a useful basis for further investigation in primary valuation studies or for the application of more sophisticated value transfer techniques such as metaregression (de Groot et al. 2012). Enlarging the number of new primary valuation studies available from Latin America and, more specifically, Mexico would be beneficial for future application of value transfer techniques as well as the design of protocols or guidelines concerning the information to be included in primary studies for value transfer purposes. In the context of the case study area, such further analyses are encouraged by the substantial size of the estimated ecosystem service values whose size corresponds to about half of the Gross Domestic Product in the entire state of Campeche (INEGI 2014).

The study also reveals interesting differences and suggests potential complementarities between different valuation techniques. Although cultural and regulating services were highly valued in the benefit transfer exercise, provisioning services, especially food and support of commercial fishing, were identified as the most important services for local communities in the semi-structured interviews. Although the latter is commonly expected in the context of

Peer) reviewing PDF | (2019:07:39851:1:2:NEW 27 Nov 2019) 
432 developing countries and regions, where food production (e.g. by fishing) sustains human well433 being by meeting basic human needs (Béné et al. 2010; Daw et al. 2011), previous studies 434 (Scholte et al. 2011; Martín-López et al. 2014) suggest that the difference with regulating 435 services, which were highly valued in the benefit transfer exercise but had the lowest relative 436 importance in the participatory interviews, may be at least partially imputed to the fact that 437 ecosystem services that provide direct benefits are often more visible to local inhabitants who 438 easily recognize how they depend on such services, while indirect benefits from cultural and 439 regulating services are less tangible or require higher expertise on the side of the respondents to

440

441

442

443

444

445

446

447

448

449

450

451

452

453

454

455

456

457

458

459

460

461

462

463

464

465

466

467

468

469

470

471 perceive them (Agbenyega et al. 2009). This suggest potential complementarities between the two approaches implemented in this study. Future studies may focus on providing a more comprehensive and representative social perception analysis of wetland ecosystem services by local communities by increasing the number of local communities and interviews, and including the perception of multiple stakeholders in order to understand their respective needs and priorities in the management of the wetlands (Iniesta-Arandia et al. 2014) and thus prevent tensions obstructing concerted action (Wilshusen et al. 2003). In addition, it is important to apply more inclusive approaches in order to evaluate local perceptions of conservation mechanisms implemented by governments in this important región, assuming that enviromental conservation will only be legitimate if local communities participate in management of natural resources and benefit from conservation (Wilshusen et al. 2002; Lele et al. 2010).

Overall, the results of the valuation components of the study are consistent with the notion that the ecosystem services provided by the Usumacinta floodplain have a significant flow of contributions to the well-being of local communities which is currently not included in the state's accounts. Future land use changes altering these ecosystems could have a significant impact on the supply of ecosystem services, and therefore on the livelihoods of the local rural communities (Fisher and Christopher 2007; Bouma et al. 2013; Delgado and Marín 2016;

Ghermandi et al. 2020). While we acknowledge that the proposed approach is a pragmatic rather than theory-driven one, which partly relies on secondary sources and combines data originally developed at different spatial scales, we believe it contributes to the development of the field insofar as: (1) it creates a bridge at the science-policy interface whereby it shows how widely used and readily recognized measures of ecosystem service values (i.e., monetary unit value transfer estimates from international repositories) can be combined with socio-cultural techniques and enriched with additional dimensions of analysis; and (2) it develops a rapid assessment tool which can be useful in providing policy-makers in data-poor countries or regions (such as, but not limited to, the investigated region in Mexico) with initial information on values and priority areas, which can be used as a starting basis for more in-depth, targeted investigation. Integrating the ecosystem service valuation analysis into a broader perspective allows to infer further recommendations for the sustainable management of the local natural capital. The implemented spatial analysis shows which of the important zones for biodiversity are faced with deep marginalization and the ecosystem services that are most relevant in those areas, thus helping to define a first prioritization of areas for intervention or, if the opportunity arises for 
472 further and more in-depth investigation. This type of integration in a spatially explicit context, is 473 crucial for identifying and communicating the relative importance of conservation activities in 474 the context of limited availability of resources for ecosystem protection and could be applied to 475 similar environments at regional, country or global level. Also, it may be useful in contexts 476 where approximate value estimates and local perceptions are sufficient to greatly improve cost477 benefit analyses for large scale developments, which can affect large areas of land, as in many 478 locations around the world, when they are projected in the short term. For example, since 1956 479 the possibility of building a dam on the Usumacinta River has been proposed. The Federal 480 Electricity Commission through its program 'Works and Investments in the Electricity Sector' 481 (CFE 2009) plans to complete the construction of Tenosique Dam Project (2017) in the 482 Usumacinta Watershed. If the construction and operation of the dam materialize, the local effects 483 might be seen in a loss of fishing productivity and bird diversity of the Centla Swamps and 484 Terminos Lagoon, ecosystems of great importance in the Usumacinta floodplain (March y Castro 485 2003). As has been shown in other important river basins around the world (Winemiller et al. 486 2016), socio-ecological consequences of disrupting river flow are often underestimated in light 487 of the potential regional benefits of hydrological energy.

Arguably, the Usumacinta floodplain wetlands are at high risk given that federal policy has concentrated on encouraging growth through increases in the Gross Domestic Product, with little consideration for other measures of well-being (Costanza et al. 2014), resulting, among others, in substantial changes in land cover over time (Ghermandi et al. 2020). The present analysis shows that the livelihoods of people living in this region still strongly depend on the flow of ecosystem services provided by the Usumacinta floodplain, many of which are provided for "free" by nature and are thus not included in national accounting. To respond to such challenge, it is increasingly common for national government through environmental institutions and academia to perform national ecosystem services assessments to answer essential questions in relation to how ecosystem services are changing, where important services originate, and what should be protected and restored to increase the provision of ecosystem services (Ouyang et al. 2016).

500

501

502

503

504

505

506

507

508

509

510

511

\section{Conclusions}

The results show that wetlands in the Usumacinta floodplain generate a significant economic estimated value; at least 4 billion USD was delivered to the inhabitants of this region in 2007, highlighting the palustrine ecosystems as the most important wetland in terms of covered area and value. Overall, cultural and provisioning services were the most relevant ecosystem services in terms of their monetary value and local perceived importance. Decision makers in this region will have to prioritize management policies in the municipality of Palizada, an area which coincides with the sites of the analysis of local perception, as well as where the three indicators in the spatial approach (ecosystem service values, marginalization and biodiversity) were highly significant.

The approach used in this study can provide a useful starting point for a more comprehensive analysis due to the ease with which the generated information and knowledge can 
512 be integrated into a more democratic policy design, and the broad scope of analysis which 513 explicitly accounts for the perception of ecosystem services by local main users and allows for 514 the internalization of the most important wetland ecosystem services in value analyses, with 515 potential benefits in terms of the improvement of the livelihoods of the local communities.

\section{Acknowledgements}

517 We would like to thank Vladimir Erives, Samuel Aguilar and Héctor Trejo (LAIGE-Ecosur) for 518 their invaluable support with the spatial analysis. We also thank Eva M. Tello, Ariel Alarcón and 519 Roberto Muñoz for her valuable assistance in the analysis of local perception. We acknowledge 520 all respondents for kindly sharing their knowledge and time.

\section{References}

522

523

524

525

526

527

528

529

530

531

532

533

534

535

536

537

538

539

540

541

542

543

544

545

546

547

548

549

Adams, W. M., Aveling, R., Brockington, D., Dickson, B., Elliott, J., Hutton, J., ... \& Wolmer, W. (2004). Biodiversity conservation and the eradication of poverty. Science, 306 (5699), 1146-1149.

Adusumilli, N. (2015). Valuation of ecosystem services from wetlands mitigation in the United States. Land, 4(1), 182-196.

Agbenyega, O., Burgess, P. J., Cook, M., \& Morris, J. (2009). Application of an ecosystem function framework to perceptions of community woodlands. Land use policy, 26(3), 551557.

Barbier, E. B., \& Strand, I. (1998). Valuing mangrove-fishery linkages-a case study of Campeche, Mexico. Environmental and Resource Economics, 12(2), 151-166.

Barbier, E. B. (2007). Valuing ecosystem services as productive inputs. Economic policy, 22(49), 178-229.

Béné, C., Hersoug, B., \& Allison, E. H. (2010). Not by rent alone: analysing the pro-poor functions of small-scale fisheries in developing countries. Development Policy Review, 28(3), 325-358.

Berlanga-Robles, C. A., Ruiz-Luna, A., \& Lanza Espino, G. D. L. (2008). Esquema de clasificación de los humedales de México. Investigaciones geográficas, (66), 25-46.

Bernues, A., Rodríguez-Ortega, T., Ripoll-Bosch, R., \& Alfnes, F. (2014). Socio-cultural and economic valuation of ecosystem services provided by Mediterranean mountain agroecosystems. PloS One, 9(7), e102479.

BirdLife International and NatureServe. (2014). Bird species distribution maps of the world. BirdLife International, Cambridge, UK and NatureServe, Arlington, USA.

Bouma, J., Joy, K. J., \& Steyn, M. (2013). Poverty, livelihoods and the conservation of nature in biodiversity hotspots around the world. In: van Beukering, P. J., Papyrakis, E., Bouma, J., Brouwer, R. (Eds.) Nature's wealth: The economics of ecosystem services and poverty. Cambridge University Press, pp. 74-103.

Brander, L. M., Bräuer, I., Gerdes, H., Ghermandi, A., Kuik, O., Markandya, A., ... \& Wagtendonk, A. (2012). Using meta-analysis and GIS for value transfer and scaling up: 
550

551

552

553

554

555

556

557

558

559

560

561

562

563

564

565

566

567

568

569

570

571

572

573

574

575

576

577

578

579

580

581

582

583

584

585

586

587

588

Valuing climate change induced losses of European wetlands. Environmental and Resource Economics, 52(3), 395-413.

Burkhard B., \& Maes, J. (Eds.) (2017) Mapping ecosystem services. Sofia: Pensoft Publishers. Camacho-Valdez, V., Ruiz-Luna, A., Ghermandi, A., \& Nunes, P. A. (2013). Valuation of ecosystem services provided by coastal wetlands in northwest Mexico. Ocean \& Coastal Management, 78, 1-11.

Campbell, J. B. (1996). Introduction to Remote Sensing. London: Taylor and Francis.

Chaikumbung, M., Doucouliagos, H., \& Scarborough, H. (2016). The economic value of wetlands in developing countries: A meta-regression analysis. Ecological Economics, 124, 164-174.

Chaikumbung, M. (2016). The ecosystem service value of coastal wetlands in developing countries: A meta-regression analysis. International Journal of Applied Business and Economic Research 14, 8519-8543

Ciftcioglu, G. C. (2017). Assessment of the relationship between ecosystem services and human wellbeing in the social-ecological landscapes of Lefke Region in North Cyprus. Landscape ecology, 32(4), 897-913.

Comisión Federal de Electricidad (CFE). (2009). Programa de obras e inversiones del sector eléctrico 2011-2025. México. 224 p.

Congalton, R. G., \& Green, K. (1999). Assessing the Accuracy of Remotely Sensed Data: Principles and Practices. USE: Lewis Publisher.

Costanza, R., d'Arge, R., De Groot, R., Farber, S., Grasso, M., Hannon, B., ... \& Raskin, R. G. (1997). The value of the world's ecosystem services and natural capital. Nature, 387(6630), 253.

Costanza, R., Kubiszewski, I., Giovannini, E., Lovins, H., McGlade, J., Pickett, K., ... \& Wilkinson, R. (2014). Time to leave GDP behind. Nature, 505 (7483): 283-285.

Daily, G. C. (1997). Nature's Services: Societal Dependence on Natural Ecosystems. USA: Island Press.

Daily, G. C., Polasky, S., Goldstein, J., Kareiva, P. M., Mooney, H. A., Pejchar, L., ... \& Shallenberger, R. (2009). Ecosystem services in decision making: time to deliver. Frontiers in Ecology and the Environment, 7(1), 21-28.

das Neves Almeida, T. A., Cruz, L., Barata, E., \& García-Sánchez, I. M. (2017). Economic growth and environmental impacts: An analysis based on a composite index of environmental damage. Ecological Indicators, 76, 119-130.

Day, J. W., Agboola, J., Chen, Z., D’Elia, C., Forbes, D. L., Giosan, L., ... \& Syvitski, J. (2016). Approaches to defining deltaic sustainability in the 21 st century. Estuarine, coastal and shelf science, 183, 275-291.

Daw, T. I. M., Brown, K., Rosendo, S., \& Pomeroy, R. (2011). Applying the ecosystem services concept to poverty alleviation: the need to disaggregate human well-being. Environmental Conservation, 38(4), 370-379.

Peer) reviewing PDF | (2019:07:39851:1:2:NEW 27 Nov 2019) 
589 Deegan, L. A., Day, Jr. J. W., Gosselink, J. G., Yanez-Arancibia, A., Chavez, G.S., Sanchez-Gil,

590

591

592

593

594

595

596

597

598

599

600

601

602

603

604

605

606

607

608

609

610

611

612

613

614

615

616

617

618

619

620

621

622

623

624

625

626

627

P. (1986). Relationships among physical characteristics, vegetation distribution and fisheries yield in Gulf of Mexico estuaries. In: Wolfe, D. A. (Ed.) Estuarine variability. USA: Academic Press, pp. 83-100.

De Groot, R., Brander, L., Van Der Ploeg, S., Costanza, R., Bernard, F., Braat, L., ... \& Hussain, S. (2012). Global estimates of the value of ecosystems and their services in monetary units. Ecosystem services, 1(1), 50-61.

Delgado, L. E., \& Marín, V. H. (2016). Well-being and the use of ecosystem services by rural households of the Río Cruces watershed, southern Chile. Ecosystem services, 21, 81-91.

Durand, L. (2019). Power, identity and biodiversity conservation in the Montes Azules Biosphere Reserve, Chiapas, Mexico. Journal of Political Ecology, 26(1), 19-37.

Eade, J. D., \& Moran, D. (1996). Spatial economic valuation: benefits transfer using geographical information systems. Journal of Environmental management, 48(2), 97-110.

Farber, S., Costanza, R., Childers, D. L., Erickson, J. O. N., Gross, K., Grove, M.,..., \& Warren, P. (2006). Linking ecology and economics for ecosystem management. Bioscience, 56(2), 121-133.

Fisher, B., \& Christopher, T. (2007). Poverty and biodiversity: measuring the overlap of human poverty and the biodiversity hotspots. Ecological economics, 62(1), 93-101.

Fisher, J. A., Patenaude, G., Meir, P., Nightingale, A. J., Rounsevell, M. D., Williams, M., \& Woodhouse, I. H. (2013). Strengthening conceptual foundations: analysing frameworks for ecosystem services and poverty alleviation research. Global Environmental Change, 23(5), 1098-1111.

García-Cuéllar, J. Á., Arreguín-Sánchez, F., Hernández Vázquez, S., \& Lluch-Cota, D. B. (2004). Impacto ecológico de la industria petrolera en la Sonda de Campeche, México, tras tres décadas de actividad: una revisión. Interciencia, 29 (6), 311-319.

García García, A., \& Kauffer Michel, E. F. (2011). Las cuencas compartidas entre México, Guatemala y Belice: un acercamiento a su delimitación y problemática general. Frontera norte, 23(45), 131-161.

Ghermandi, A., Van Den Bergh, J. C., Brander, L. M., de Groot, H. L., \& Nunes, P. A. (2010). Values of natural and human-made wetlands: A meta-analysis. Water Resources Research, 46(12).

Ghermandi, A., Ding, H., \& Nunes, P. A. (2013). The social dimension of biodiversity policy in the European Union: Valuing the benefits to vulnerable communities. Environmental science \& policy, 33, 196-208.

Ghermandi, A., Camacho-Valdez, V., \& Trejo-Espinosa, H. (2020). Social media-based analysis of cultural ecosystem services and heritage tourism in a coastal region of Mexico. Tourism Management 77, 104002.

Gómez-Baggethun, E., Martín-López, B., Barton, D., Braat, L., Saarikoski, H., Kelemen,.., SchröterSchlaack, C., Harrison, P. (2014). State-of-the-art report on integrated valuation of

Peer] reviewing PDF | (2019:07:39851:1:2:NEW 27 Nov 2019) 
628

629

630

631

632

633

634

635

636

637

638

639

640

641

642

643

644

645

646

647

648

649

650

651

652

653

654

655

656

657

658

659

660

661

662

663

664

665

ecosystem services. EU FP7 OpenNESS Project Deliverable 4.1., European Commission FP7

Haines-Young, R., \& Potschin, M. B. (2018). Common International Classification of Ecosystem Services (CICES) V5.1 and Guidance on the Application of the Revised Structure. Available from: www.cices.eu.

Hare, M., \& Pahl-Wostl, C. (2002). Stakeholder categorisation in participatory integrated assessment processes. Integrated Assessment, 3(1), 50-62.

Iniesta-Arandia, I., García-Llorente, M., Aguilera, P. A., Montes, C., \& Martín-López, B. (2014). Socio-cultural valuation of ecosystem services: uncovering the links between values, drivers of change, and human well-being. Ecological Economics, 108, 36-48.

Jacobs, S., Dendoncker, N., Martín-López, B., Barton, D. N., Gomez-Baggethun, E., Boeraeve, F., ... \& Pipart, N. (2016). A new valuation school: Integrating diverse values of nature in resource and land use decisions. Ecosystem Services, 22, 213-220.

Hare, M. (2011). Forms of participatory modelling and its potential for widespread adoption in the water sector. Environmental Policy and Governance, 21(6), 386-402.

INEGI. (2008). Características edafológicas, fisiográficas, climáticas e hidrográficas de México. Instituto Nacional de Estadística Geografía e Informática, México, p 32.

INEGI. (2010). Estadísticas Históricas de México 2009. Instituto Nacional de Estadística Geografía e Informática, México.

INEGI. (2014). Producto Interno Bruto por Entidad Federativa Variación porcentual anual. http://www.inegi.org.mx/est/contenidos/proyectos/cn/pibe/.

IPBES (2016) Preliminary guide regarding diverse conceptualization of multiple values of nature and its benefits, including biodiversity and ecosystem functions and services. Available online at http://www.ipbes.net/sites/default/files/downloads/IPBES-4-INF-13_EN.pdf (Accessed 29/10/2019).

Kanyiginya, V., Kansiime, F., Kimwaga, R., \& Mashauri, D. A. (2010). Assessment of nutrient retention by Natete wetland Kampala, Uganda. Physics and Chemistry of the Earth, Parts $A / B / C, 35(13-14), 657-664$.

Kati, V., Devillers, P., Dufrêne, M., Legakis, A., Vokou, D., \& Lebrun, P. (2004). Testing the value of six taxonomic groups as biodiversity indicators at a local scale. Conservation biology, 18(3), 667-675.

Kaul, S., Boyle, K. J., Kuminoff, N. V., Parmeter, C. F. \& Pope, J. C. (2013) What can we learn from benefit transfer errors? Evidence from 20 years of research on convergent validity. Journal of Environmental Economics and Management 66(1), 90-104.

Johnston, R. J. \& Rosenberger R.S. (2010). Methods, Trends and controversies in contemporary benefit transfer. Journal of Economic Surveys, 24,479-510.

Johnston, R.J., Rolfe, J., Rosenberger, R.S., Brouwer R. (2015) (eds). Benefit transfer of environmental and resource values. Springer, Dordrecht. 
666 Lara-Domínguez, A. L., Arreguín, F., \& Álvarez-Guillén, H. (1993). Biodiversity and the use of

667

668

669

670

671

672

673

674

675

676

677

678

679

680

681

682

683

684

685

686

687

688

689

690

691

692

693

694

695

696

697

698

699

700

701

702

703

704 natural resources: the fish communities in the southern Gulf of Mexico. Revista de la Sociedad Mexicana de Historia Natural, 44, 345-385

Lautenbach, S., Kugel, C., Lausch, A., \& Seppelt, R. (2011). Analysis of historic changes in regional ecosystem service provisioning using land use data. Ecological Indicators, 11(2), 676-687.

Lavorel, S., \& Grigulis, K. (2012). How fundamental plant functional trait relationships scale-up to trade-offs and synergies in ecosystem services. Journal of Ecology, 100(1), 128-140.

Lele, S., Wilshusen, P., Brockington, D., Seidler, R., \& Bawa, K. (2010). Beyond exclusion: alternative approaches to biodiversity conservation in the developing tropics. Current opinion in environmental sustainability, 2(1-2), 94-100.

Lindhjem H., Navrud, S. (2008) How reliable are meta-analyses for international value transfer? Ecological Economics 66(2-3): 425-435.

Liu, S., Portela, R., Ghermandi, A., Rao, N., Wang, X. (2012) Environmental benefits transfer of ecosystem services valuation. In M. van den Belt and R. Costanza (eds.) Volume 12, Ecological Economics of Estuaries and Coasts. In E. Wolanski and D.S. McLusky (eds.) Treatise on Estuarine and Coastal Science, Waltham MA: Academic Press, pp. 55-77.

Luck, G. W., Chan, K. M., \& Fay, J. P. (2009). Protecting ecosystem services and biodiversity in the world's watersheds. Conservation Letters, 2(4), 179-188.

Maccherini, S., Bacaro, G., Favilli, L., Piazzini, S., Santi, E., \& Marignani, M. (2009). Congruence among vascular plants and butterflies in the evaluation of grassland restoration success. Acta oecologica, 35(2), 311-317.

Mahdavi, S., Salehi, B., Granger, J., Amani, M., Brisco, B., \& Huang, W. (2018). Remote sensing for wetland classification: A comprehensive review. GIScience \& remote sensing, 55(5), 623-658.

Martín-López, B., Gómez-Baggethun, E., García-Llorente, M., \& Montes, C. (2014). Trade-offs across value-domains in ecosystem services assessment. Ecological indicators, 37, 220 228.

Meli, P., Landa, R., López-Medellín, X., \& Carabias, J. (2015). Social perceptions of rainforest and climatic change from rural communities in Southern Mexico. Ecosystems, 18(8), 13431355.

Mendoza-González, G., Martínez, M. L., Lithgow, D., Pérez-Maqueo, O., \& Simonin, P. (2012). Land use change and its effects on the value of ecosystem services along the coast of the Gulf of Mexico. Ecological Economics, 82, 23-32.

Millennium Ecosystem Assessment (MEA). (2005). Ecosystems and Human Well-being: Biodiversity Synthesis. Washington, DC: World Resources Institute.

Muñoz-Salinas, E., \& Castillo, M. (2015). Streamflow and sediment load assessment from 1950 to 2006 in the Usumacinta and Grijalva Rivers (Southern Mexico) and the influence of ENSO. Catena, 127, 270-278. 
705

706

707

708

709

710

711

712

713

714

715

716

717

718

719

720

721

722

723

724

725

726

727

728

729

730

731

732

733

734

735

736

737

738

739

740

741

742

Naidoo, R., Balmford, A., Costanza, R., Fisher, B., Green, R. E., Lehner, B., ... \& Ricketts, T. H. (2008). Global mapping of ecosystem services and conservation priorities. Proceedings of the National Academy of Sciences, 105(28), 9495-9500.

Nilsson, C., Reidy, C. A., Dynesius, M., \& Revenga, C. (2005). Fragmentation and flow regulation of the world's large river systems. Science, 308(5720), 405-408.

Ouyang, Z., Zheng, H., Xiao, Y., Polasky, S., Liu, J., Xu, W., ... \& Jiang, L. (2016).

Improvements in ecosystem services from investments in natural capital. Science, 352(6292), 1455-1459.

Pahl-Wostl, C., \& Hare, M. (2004). Processes of social learning in integrated resources management. Journal of Community \& Applied Social Psychology, 14(3), 193-206.

Pendleton, L. H., Thébaud, O., Mongruel, R. C., \& Levrel, H. (2016). Has the value of global marine and coastal ecosystem services changed?. Marine Policy, 64, 156-158.

Prendergast, J. R., Quinn, R. M., Lawton, J. H., Eversham, B. C., \& Gibbons, D. W. (1993). Rare species, the coincidence of diversity hotspots and conservation strategies. Nature, 365(6444), 335.

Raudsepp-Hearne, C., Peterson, G. D., \& Bennett, E. M. (2010). Ecosystem service bundles for analyzing tradeoffs in diverse landscapes. Proceedings of the National Academy of Sciences, 107(11), 5242-5247.

Renaud, F. G., Syvitski, J. P., Sebesvari, Z., Werners, S. E., Kremer, H., Kuenzer, C., ... \& Friedrich, J. (2013). Tipping from the Holocene to the Anthropocene: How threatened are major world deltas?. Current Opinion in Environmental Sustainability, 5(6), 644-654.

Richards, D. R., Warren, P. H., Moggridge, H. L., \& Maltby, L. (2015). Spatial variation in the impact of dragonflies and debris on recreational ecosystem services in a floodplain wetland. Ecosystem services, 15, 113-121.

Rongoei, P. J. K., Kipkemboi, J., Okeyo-Owuor, J. B., \& Van Dam, A. A. (2013). Ecosystem services and drivers of change in Nyando floodplain wetland, Kenya. African Journal of Environmental Science and Technology, 7(5), 274-291.

De la Rosa-Velázquez, M. I., Espinoza-Tenorio, A., Díaz-Perera, M. Á., Ortega-Argueta, A., Ramos-Reyes, R., \& Espejel, I. (2017). Development stressors are stronger than protected area management: A case of the Pantanos de Centla Biosphere Reserve, México. Land Use Policy, 67, 340-351.

Rosenberger, R. S. (2015) Benefit transfer validity and reliability. In Johnstone, R.J., Rolfe, J., Rosenberger, R.S. and Brouwer, R. (eds), Benefit Transfer of Environmental and Resource Values: A Guide for Researchers and Practitioners. Dordrecht, Heidelberg, New York, London, Springer, pp. 307-326.

Rosenberger, R. S., \& Phipps, T. T. (2007). Correspondence and convergence in benefit transfer accuracy: meta-analytical review of the literature. In: Navrud, S., \& Ready, R. (Eds.), Environmental Value Transfer: Issues and Methods. Netherlands; Springer, Dordrecht. 
743 Ruckelshaus, M., McKenzie, E., Tallis, H., Guerry, A., Daily, G., Kareiva, P., ... \& Bernhardt, J.

744

745

746

747

748

749

750

751

752

753

754

755

756

757

758

759

760

761

762

763

764

765

766

767

768

769

770

771

772

773

774

775

776

777

778

779

780

781 (2015). Notes from the field: lessons learned from using ecosystem service approaches to inform real-world decisions. Ecological Economics, 115, 11-21.

Santi, E., Maccherini, S., Rocchini, D., Bonini, I., Brunialti, G., Favilli, L., ... \& Salerni, E. (2010). Simple to sample: vascular plants as surrogate group in a nature reserve. Journal for Nature Conservation, 18(1), 2-11.

Schmidt, K., Sachse, R., \& Walz, A. (2016). Current role of social benefits in ecosystem service assessments. Landscape and Urban Planning, 149, 49-64.

Scholte, S. S., van Teeffelen, A. J., \& Verburg, P. H. (2015). Integrating socio-cultural perspectives into ecosystem service valuation: a review of concepts and methods. Ecological economics, 114, 67-78.

Scoones, I. (1998). Sustainable rural livelihoods: a framework for analysis. IDS Working Paper 72: $1-22$.

Sjöstedt, M. (2012). Ecosystem services and poverty reduction: how do development practitioners conceptualize the linkages?. The European Journal of Development Research, 24(5), 777-787.

Shrestha, R. K., \& Loomis, J. B. (2001). Testing a meta-analysis model for benefit transfer in international outdoor recreation. Ecological Economics, 39(1), 67-83.

Sundberg, J. (2003). Conservation and democratization: constituting citizenship in the Maya Biosphere Reserve, Guatemala. Political Geography, 22(7), 715-740.

Sundberg, J. (2006). Conservation encounters: transculturation in the "contact zone" of empire. Cultural Geographies, 13(2): 239-265.

TEEB-Foundations (2010). In: Kumar, P. (Ed.). The Economics of Ecosystems and Biodiversity: Ecological and Economic Foundations. Earthscan, London, Washington.

TEEB in Policy (2011). In: ten, Brink, P. (Ed.). The Economics of Ecosystems and Biodiversity in National and International Policy Making. Earthscan, London, Washington.

Tudela, F. (1989). La modernización forzada del trópico: el caso de Tabasco: proyecto integrado del Golfo. Instituto Politécnico Nacional, Centro de Investigación y de Estudios Avanzados. Instituto de Investigaciones de las Naciones Unidas para el Desarrollo Social, El Colegio de México.

Van der Ploeg, S., Wang, Y., Gebre Weldmichael, T., \& de Groot, R. S. (2010). The TEEB Valuation Database - a searchable database of 1310 estimates of monetary values of ecosystem services. Foundation for Sustainable Development, Wageningen, The Netherlands.

Wam, H.K., Bunnefeld, N., Clarke, N., \& Hofstad, O. (2016). Conflicting interest of ecosystem services: multicriteria modelling and indirect evaluation to trade off monetary and nonmonetary measures. Ecosystem Services, 22B, 280-288.

Wilkerson, S. J.K. (1986). Damming the Usumacinta: the archaeological impact. Mesa Redonda de Palenque, Chiapas. USA: The University of Oklahoma Press, 118-134. 
782

783

784

785

786

787

788

789

790

791

792

793

794

795

796

797

798

799

800

801

802

803

804

805

806

807

808

809

810

Wilshusen, P.R., Brechin, S.T., Fortwrangler, C.L., \& West, P.C. (2002). Reinventing the Square Wheel: Critique of a Resurgent 'Protection Paradigm' in International Biodiversity Conservation. Society and Natural Resources, 15: 1-40.

Wilshusen, P.R. (2003). Exploring the political contours of conservation. A conceptual view of power in practice. In Brechin, S.R., Wilshusen, P.R., Fortwrangler, C.L., \& West, P.C. (eds.), Contested Nature. Promoting International Biodiversity with Social Justice in the Twenty-First Century. State University of New York, New York, pp. 41-58.

Wilson, M., Troy, A., \& Costanza, R. (2004). The economic geography of ecosystem goods and services: revealing the monetary value of landscapes through transfer methods and Geographic Information Systems. In: Dietrich, M., Straaten, V. D. (Eds.), Cultural Landscapes and Land Use. The Netherlands: Kluwer, Dordrecht, pp. 69-94.

Winemiller, K. O., McIntyre, P. B., Castello, L., Fluet-Chouinard, E., Giarrizzo, T., Nam, S., ... \& Stiassny, M. L. J. (2016). Balancing hydropower and biodiversity in the Amazon, Congo, and Mekong. Science, 351(6269), 128-129.

Wu, J. (2013). Landscape sustainability science: ecosystem services and human well-being in changing landscapes. Landscape ecology, 28(6), 999-1023.

Yáñez-Arancibia, A., \& Day Jr, J. W. (1982). Ecological characterization of Terminos Lagoon, a tropical lagoon-estuarine system in the southern Gulf of Mexico. Oceanologica Acta, 5(4), 431-440.

Yañez-Arancibia, A., Aguirre-León, A., \& Soberón-Chavez, G. (1992). Estuarine-related fisheries in Terminos lagoon and adjacent continental shelf (Southern Gulf of Mexico). In: Conservation and Development: the Sustainable Use of Wetlands Resources. Proc. 3rd Int. Wetland Conf., Rennes (pp. 145-153). IUCN Gland, Switzerland.

Yáñez-Arancibia, A., \& Day, J. W. (2004). Environmental sub-regions in the Gulf of Mexico coastal zone: the ecosystem approach as an integrated management tool. Ocean \& Coastal Management, 47(11-12), 727-757.

Yáñez-Arancibia, A., Day, J. W., \& Currie-Alder, B. (2009). Functioning of the GrijalvaUsumacinta river delta, Mexico: Challenges for coastal management. Ocean Yearbook 23, 473-501. 
Figure 1

Study area. Usumacinta floodplain (UFP), southern Mexico. Location of surveyed villages. The layers are derived from INEGI open data.

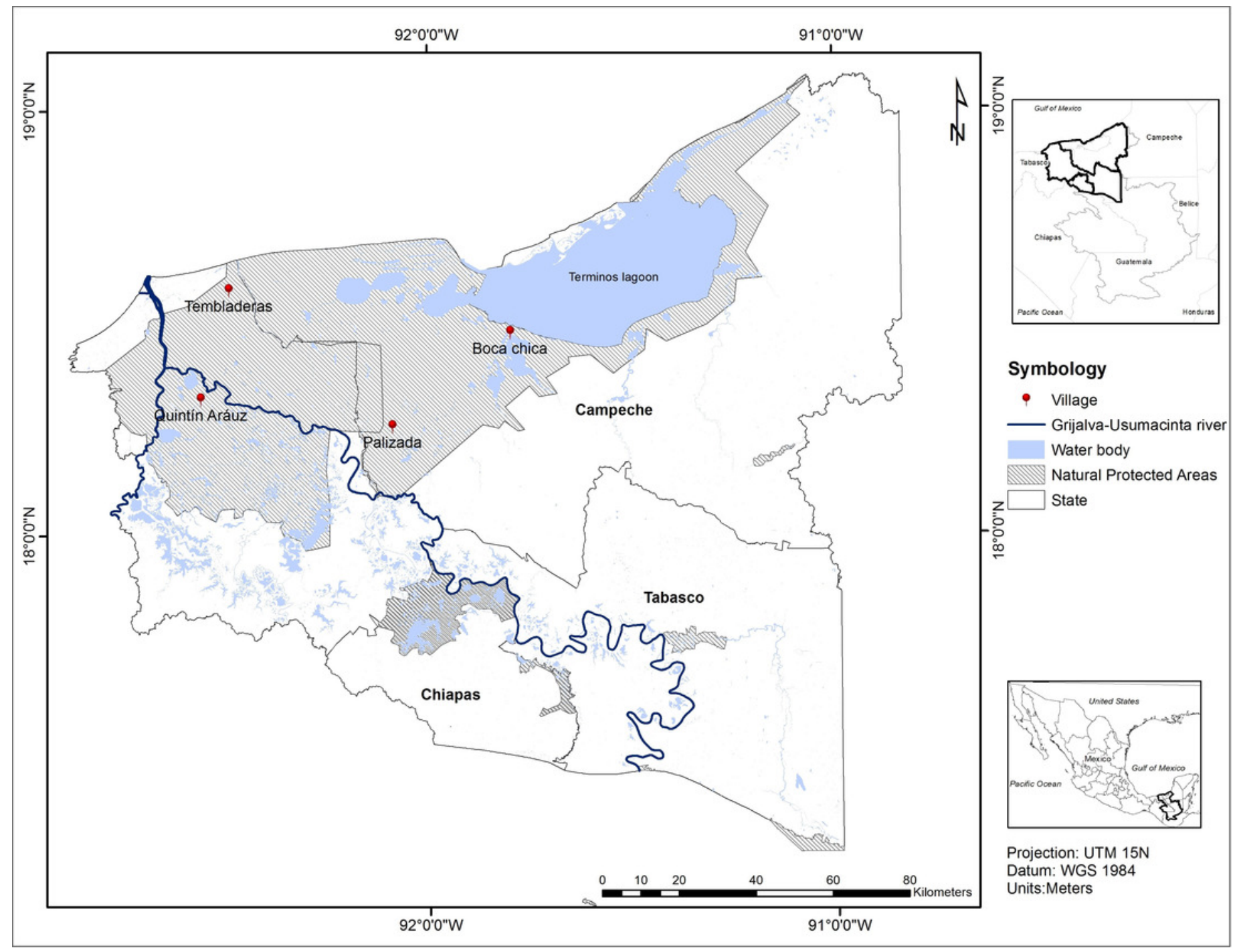


Figure 2

The methodological approach for ecosystem valuation in the Usumacinta floodplain (Modified from TEEB (2011), Ciftcioglu (2017) and Haines-Young and Potschin (2018)).

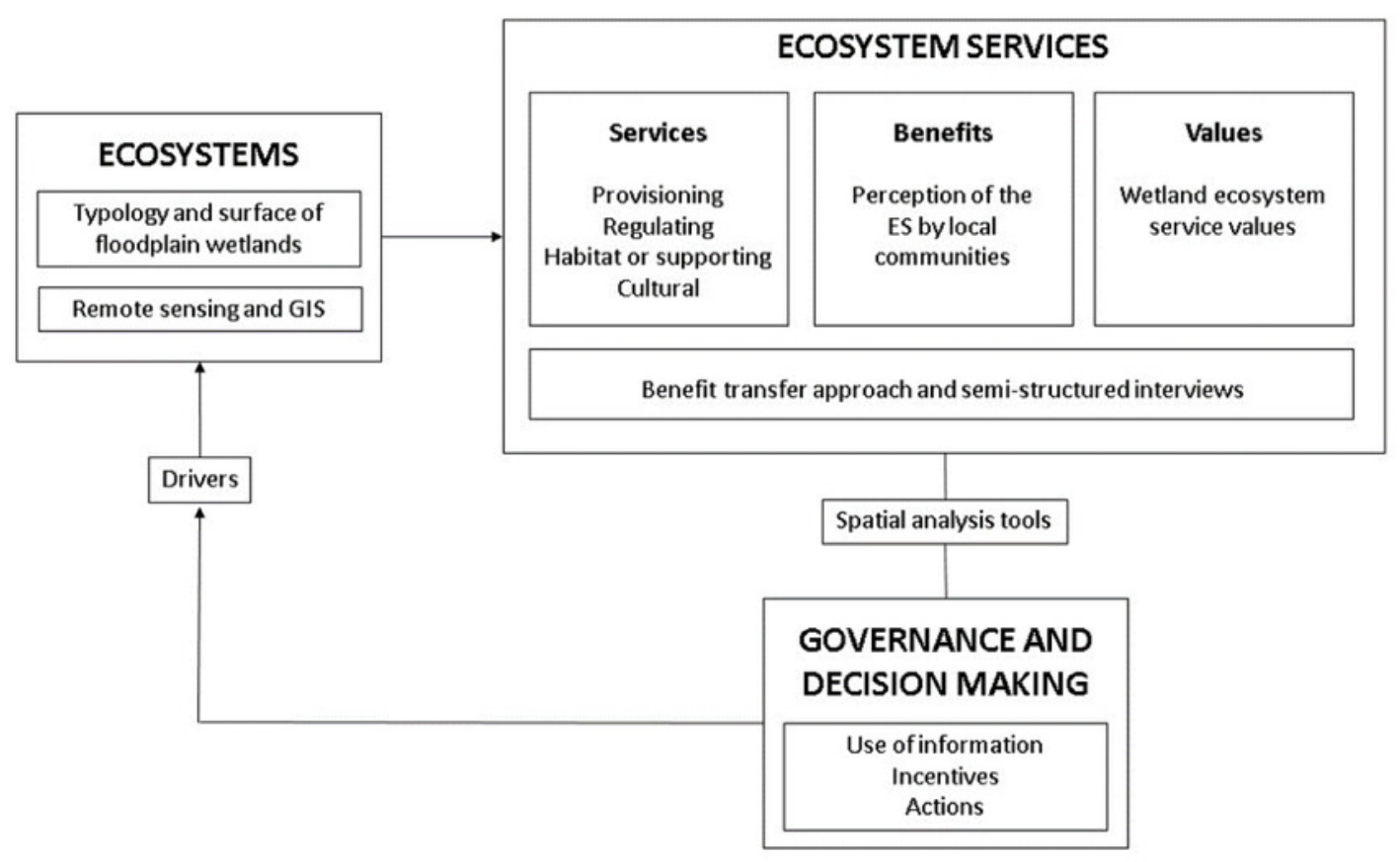


Figure 3

An example of a cognitive map derived from the semi-structured interview. Photo: Ellinor Roth.

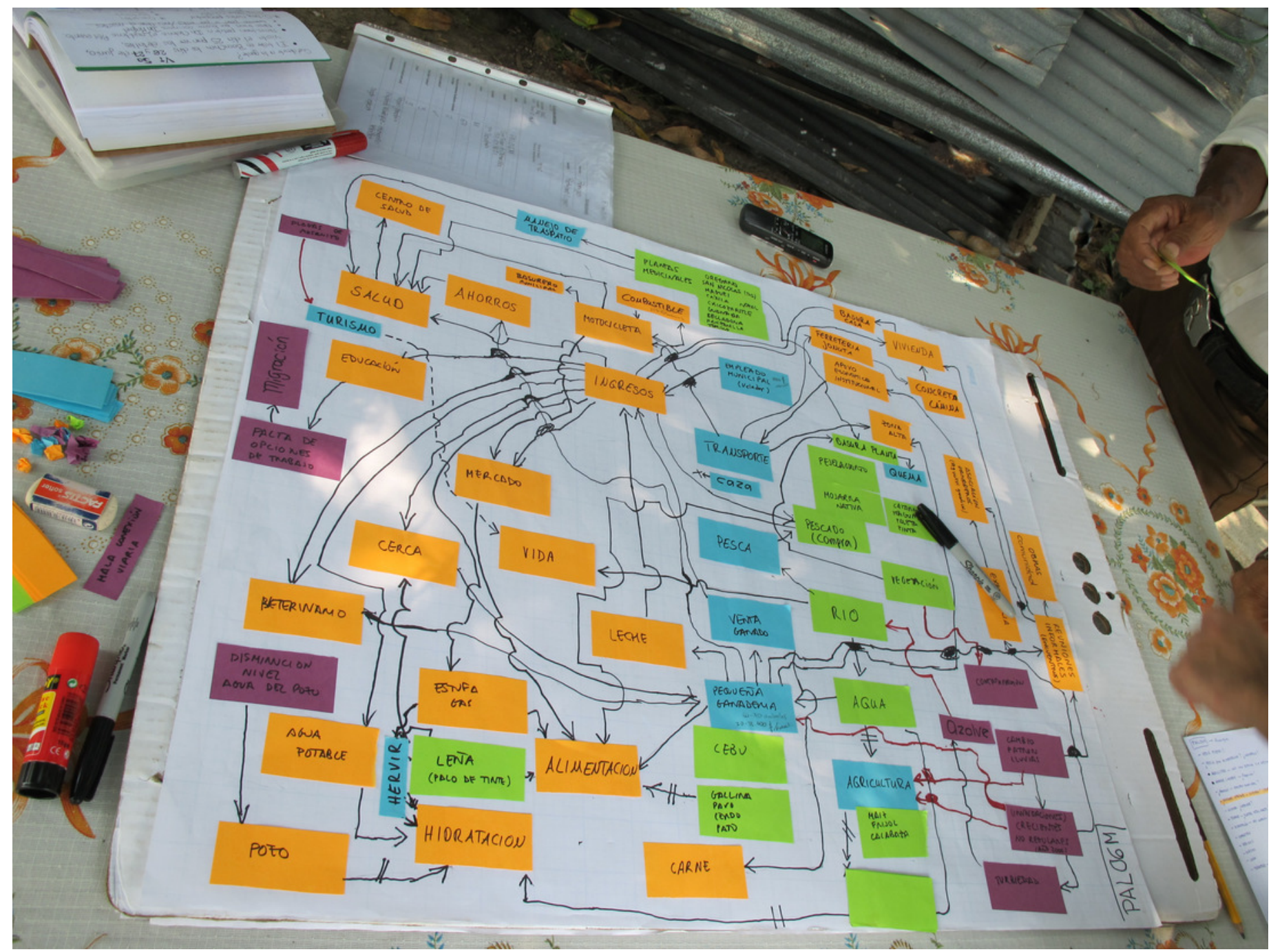


Figure 4

Classification of land use and land cover in the UFP from 2014 Landsat TM free imagery.

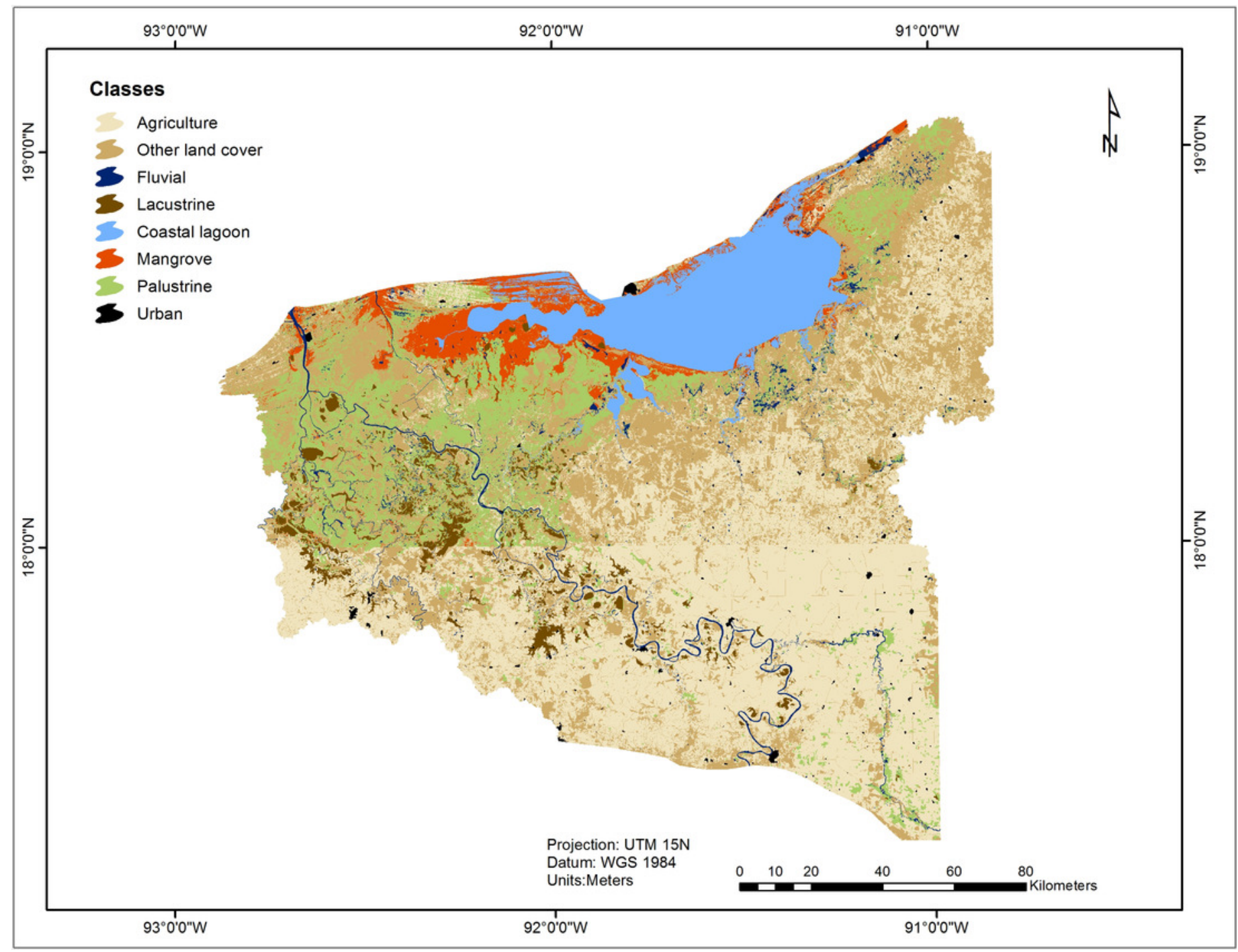


Figure 5

Frequency of occurrence (\%) of ecosystem services in the four communities where people were interviewed. Food category includes: fish and crustaceans.

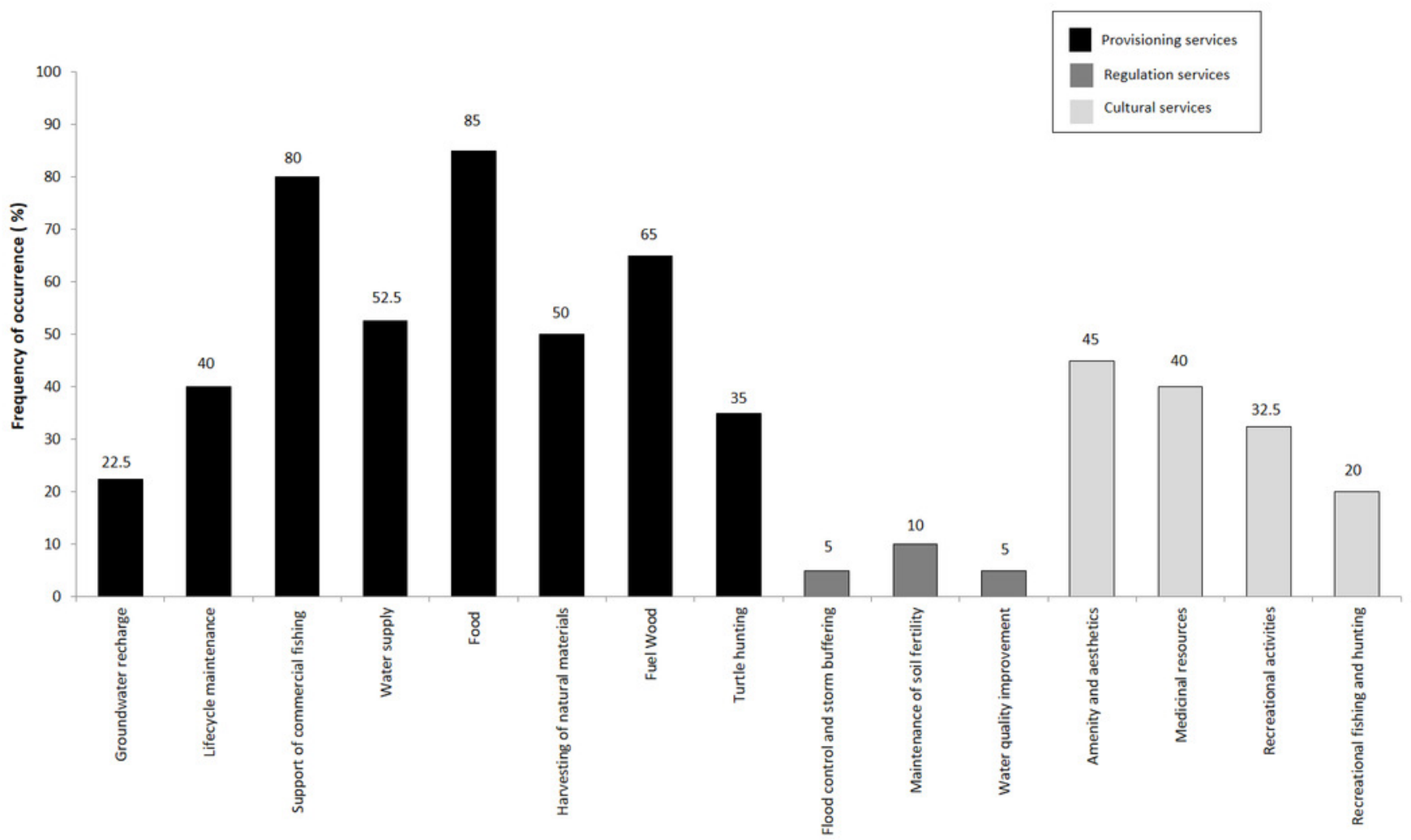




\section{Figure 6}

a) Ranking of priority conservation wetland areas based on overlapping of ecosystem service values, socioeconomic and biodiversity indexes; b) Overlap of socioeconomic and biodiversity indicators with the estimated ecosystem service values in the Usumacin
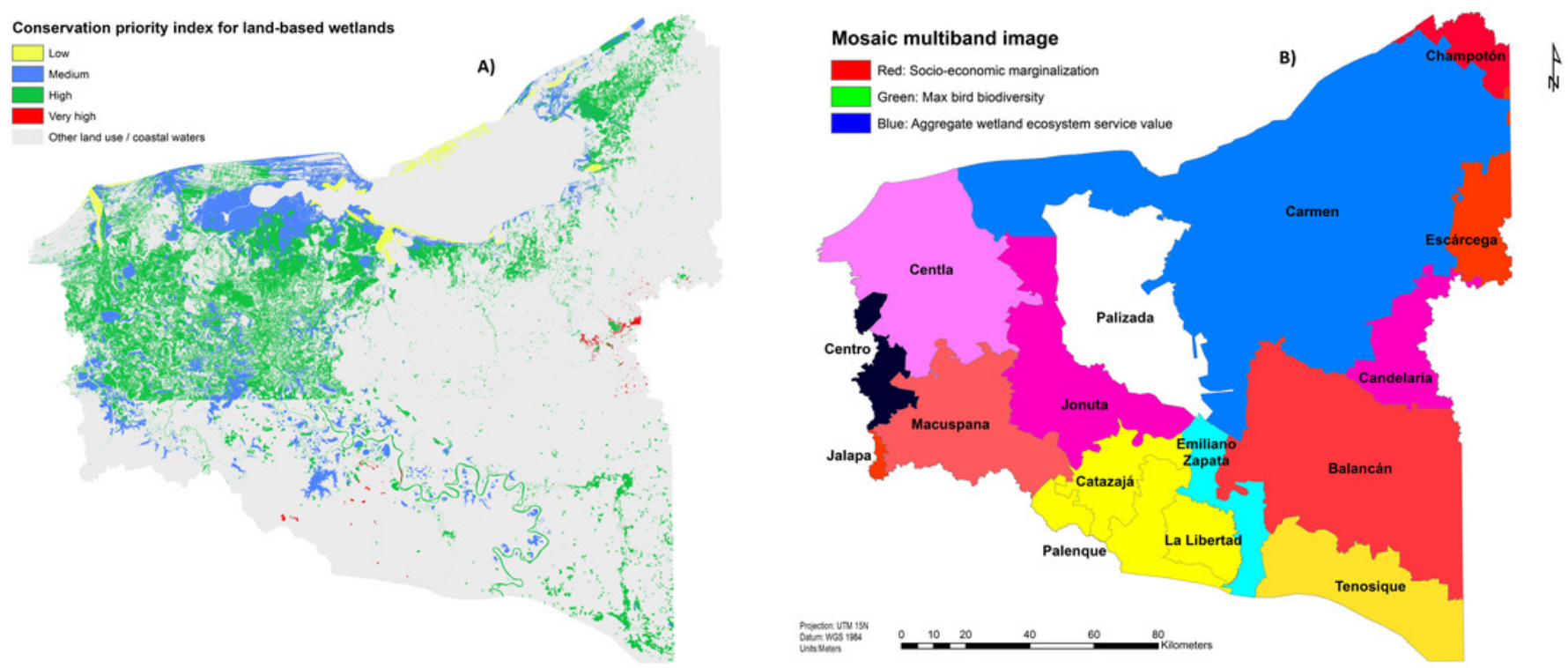


\section{Table 1 (on next page)}

General characteristics of the four selected communities. 


\begin{tabular}{|c|c|c|c|c|}
\hline & Quintín Arauz & Tembladeras & Palizada & Boca Chica \\
\hline Location & Near the main river & Near the mangroves & Near a tributary & $\begin{array}{l}\text { Near the coastal } \\
\text { lagoon }\end{array}$ \\
\hline Population $^{a}$ & 1,000 inhanitants & 200 inhabitants & 1,000 inhabitants & 15 households \\
\hline Type of settlement ${ }^{a}$ & $\begin{array}{l}\text { Concrete homes } \\
\text { Paved roads } \\
\text { Church } \\
\text { Health center } \\
\text { School }\end{array}$ & Precarious houses & $\begin{array}{l}\text { Concrete homes } \\
\text { Paved roads } \\
\text { Church } \\
\text { Health center } \\
\text { School }\end{array}$ & Precarious houses \\
\hline Seniority of the community & 200 years & 40 years & 300 years & 60 years \\
\hline $\begin{array}{l}\text { Level environment } \\
\text { transformation }\end{array}$ & High & Low & High & Low \\
\hline Economic activities & Fishing/livestock & Fishing & Fishing/livestock/tourism & Fishing \\
\hline Ethnicity & Chontal & Mixed & Mixed & Mixed \\
\hline Education $^{a}$ & Low-medium & Low & Low-medium-high & Low \\
\hline
\end{tabular}

2 aBased on INEGI (2010)

3 


\section{Table 2 (on next page)}

Table 2. Summary of estimated values for each service per wetland type derived from the value transfer exercise. The total ecosystem service values per wetland type obtained from adding the median values per ES (in bold). Values in 2007 USD/ha/year. 


\begin{tabular}{|c|c|c|c|c|c|c|c|}
\hline & \# obs. & Mangrove & Coastal lagoon & Palustrine & Riverine & Lacustrine & $\begin{array}{c}\text { Total ES median } \\
\text { value }\end{array}$ \\
\hline Provisioning services & 135 & 1,325 & 281 & 4,845 & 1,085 & 478 & 8,014 \\
\hline Support of commercial fishing & 57 & 380 & 122 & 67 & 822 & 446 & 1,838 \\
\hline Water supply & 18 & 683 & 3 & 1286 & 18 & 24 & 2,014 \\
\hline Harvesting of natural materials & 39 & 213 & 156 & 3353 & 65 & 8 & 3,794 \\
\hline Fuel Wood & 20 & 48 & & 26 & 180 & & 254 \\
\hline Ornamental resources & 1 & & & 114 & & & 114 \\
\hline Regulating services & 47 & 690 & 17 & 2322 & 4,399 & 23 & 7,452 \\
\hline Local climate control & 1 & 7 & & & & & 7 \\
\hline Flood control and storm buffering & 30 & 683 & 17 & 1661 & 4,291 & 23 & 6,677 \\
\hline Water quality improvement & 16 & & & 661 & 108 & & 769 \\
\hline Habitat or supporting services & 21 & 247 & 0 & 55 & 2,145 & 4,369 & 6,816 \\
\hline Maintenance of genetic diversity & 1 & & & 31 & & & 31 \\
\hline Habitat for species & 20 & 247 & & 24 & 2,145 & 4,369 & 6,785 \\
\hline Cultural services & 40 & 391 & 1629 & 2467 & 5,202 & 1,496 & 11,185 \\
\hline Amenity and esthetics & 9 & & 460 & & 3,291 & 495 & 4,245 \\
\hline Recreational activities & 20 & 362 & 151 & 2,430 & 1,253 & 896 & 5,093 \\
\hline Recreational fishing and hunting & 11 & 28 & 1018 & 37 & 658 & 105 & 1,847 \\
\hline $\begin{array}{l}\text { Median total value per ecosystem type } \\
\text { (2007 USD/ha/year) }\end{array}$ & & 2,653 & 1,926 & 9,689 & 12,833 & 6,366 & \\
\hline $\begin{array}{l}\text { Area } \\
(\text { ha) }\end{array}$ & & 108,600 & 228,201 & 320,285 & 54,178 & 62,442 & \\
\hline $\begin{array}{l}\text { Annual ecosystem service flow }{ }^{b} \\
\text { (2007 USD/year) }\end{array}$ & & $288,105,575$ & $439,619,915$ & $3,103,293,877$ & $695,246,902$ & $397,517,290$ & $4,923,783,558^{c}$ \\
\hline
\end{tabular}

Extension of the wetland in hectares

bAnnual ecosystem service flow was calculated multiplying the total ecosystem service value by the wetland area.

cTotal economic value (TEV) was calculated by adding the value of the annual flow of ecosystem services by wetland type

Wetland description. Mangrove: forested-shrub estuarine wetland: plant association formed by one or a combination of the four species of mangrove; coastal lagoon: subtidal

estuarine wetland; palustrine: palustrine continental wetland (where there is permanent water): swamp, marshes, tular, popal; riverine: permanent riverine wetland: rivers and

channels; and lacustrine: lacustrine continental wetland, permanent and seasonal: lake, ponds, body of water. 